\title{
The Relationship among Perceived Organizational Support, Trust, Job Satisfaction and Turnover Intention: A Study of Banking Sector in Pakistan
}

\author{
Ali Hasan (corresponding author) \\ Department of Management and administrative sciences, University of Narowal \\ EID Gah Road Jilani Colony Street No. 5 Narowal, Pakistan \\ E-mail: ahasan.hasan4@gmail.com
}

\author{
Shala Noreen \\ Department of Management and administrative sciences \\ University of Narowal, Pakistan \\ E-mail: Razaq-Sheila@yahoo.com \\ Muhammad Mohsin \\ Department of Management and administrative sciences \\ University of Narowal, Pakistan \\ E-mail: Mohsinhafeez007@gmail.com
}

Received: Sep. 24, 2018 Accepted: Oct. 22, 2018 Online published: Nov. 27, 2018

doi:10.5296/ijhrs.v8i4.13686

URL: https://doi.org/10.5296/ijhrs.v8i4.13686

\begin{abstract}
This research inspects the impact of POS on trust, job satisfaction and turnover intention and observe the mediating effect of job satisfaction between POS, trust and turnover intention. A sample of 281 is taken from the banking sector. Convenience Sampling is used. The scales are taken from earlier research and confirmed for validity \& reliability. Eight hypotheses are explored. Data is analyzed through descriptive statistics and multiple regression. Results indicated that POS positively affected trust and job satisfaction, so did trust on job satisfaction. POS, trust and job satisfaction negatively affected turnover intention and the
\end{abstract}


results are consistent with previous researches. Job satisfaction performed as partial mediator between POS and turnover intention; trust and turnover intention. The study is useful but also suffers from some limitations. This study was done on banking sector so it can only apply to banking sector. Other sector like education and health sector were missing. Time was limited, sample size was not too big. The findings of this study shows the importance of POS, trust and job satisfaction in affecting turnover intention in banking sector. For minimizing turnover intention mangers in this sector must consider these indicators. The research for the relation among said variables has been abundant in past, but in this area the research is still lacking so the gap is still there.

Keywords: POS, trust, turnover intention, job satisfaction, mediator, banking sector

\section{Introduction}

With significant headways in tasks of business entities and increment in desires from clients, organizations today confront massive difficulties, both from inside and outside. Among these difficulties, holding a skilled and experienced workforce is likewise viewed as an accomplishment. In such manner, turnover rate is considered as a critical measure of the proficiency and adequacy of an organization's execution and its administration's strategies. This rate postures more prominent difficulties to the organizations because it is difficult to comprehend, control and react to the exchanging workers.

Due to fierce competition it has become a challenge for employers to survive. Having best human resource is a very important key to remain competitive (Islam, Khan, \& Bukhari, 2016). In this way, every business needs to have best human asset that has made an issue of representative turnover intention, since they can move starting with one association then onto the next. According to annual report of State Bank of Pakistan 2013-2014, employee turnover has become worse, a total of $24 \%$ employee resigned their jobs. A new employee cost ten times more rather than retaining the old one (Robbins, Judge, \& Sanghi, 2005). In numerous disciplines and the social sciences by and large, the study of turnover and turnover intention has been and still is well known theme (Coomber \& Barriball, 2007).

Experts are occupied with to know the effect of different employee attitudes and behavior on the basic human resource management issues that they are confronting (Bright, 2008). There are many predictors of turnover intention which have been examined in the past including POS (Allen, Shore, \& Griffeth, 2003) trust (Jay Prakash Mulki, Jaramillo, \& Locander, 2006) and Job satisfaction (Coomber \& Barriball, 2007). The exchange relationship between employer and employees have been significantly contributed by researchers in last few years (Islam et al., 2016). These investigations propose that representative's view of great treatment' will deliver positive results for the organization. (Eisenberger, Huntington, Hutchison, \& Sowa, 1986), all the more particularly, centered on the worker association connection and named it as Perceived organizational support. There is less expectation to leave the association by those representatives who perceive good treatment (Allen et al., 2003)

A lot of studies have been done to explore the relationship between job satisfaction and turnover intention in past (Hellman, 1997). Most of these studies have showed that intention 
to leave and probability of turnover increases due to job dissatisfaction (Saeed, Waseem, Sikander, \& Rizwan, 2014). Several of factors are considered important for the job satisfaction. Employment can be impacted by assortment of variables like nature of one's association with the supervisor, nature of physical condition in which one works and the level of satisfaction in one's work. Job satisfaction may also come from factors named trust (DeConinck, 2011; Harhara, Singh, \& Hussain, 2015) and POS (Imran, Ali, \& Islam, 2014). Trust has turned out to be one of a vital topic for some discipline in past. Both of the variables namely trust (Jay Prakash Mulki et al., 2006) and job satisfaction (G. J. Blau, 1987; Saeed et al., 2014) are strongly related with turnover intention.

So The purposes of this study is to (1) explore the effect of employee POS on Job satisfaction, Trust, turnover intention (2) verify the impact of employee job satisfaction and trust on turnover intention; (3) explore the mediating effect of job satisfaction between POS and turnover intention; between Trust and turnover intention.

\section{Literature Review}

\subsection{Influence of POS on Study Variables}

As per Eisenberger, Huntington et al. 1986, perceived organization support is the workers' conviction, discernment or judgment of how much the organization thinks about them and values their commitment. The concept of this is taken from social exchange theory (P. Blau, 1964). Social exchange theory is the perspective of that there is equal exchange relationship among parties, when somebody gives something significant to the collector, at that point the recipient responds it emphatically. Likewise, workers give positive job related results i.e., job satisfaction, lessened turnover intention and trust each other, when they feel support from the organization.

In organizational behavior literature, the relation between POS and Organizational trust widely studied. POS was a mediator between organizational justice and employee's overall trust in organization (DeConinck, 2011; Stinglhamber, Cremer, \& Mercken, 2006). Perception about support is built over time with the demonstration of beneficial decisions (career progression, rewards, developmental experiences, etc.) by superiors (Wayne, Shore, \& Liden, 1997). POS played a mediating role between HR practices and organizational trust found by (Narang \& Singh, 2012). POS and trust was positively and significantly correlated (Shukla \& Rai, 2015). Ristig (2009) also found positive and significant relationship between POS and trust. Thus, hypothesis 1 is as follows

\section{H.1 Employee's POS positively influence Trust}

Research suggests that employees feel a sense of praise, support, or approval from their organization if they get the support from organization (Aselage \& Eisenberger, 2003). Specifically, research indicated that individuals are more likely to be satisfied with their jobs if they perceive their organization supports them (Allen et al., 2003). According to Yih-Wann, Wu., \& Htaik, Sein. (2011) there is positive relationship between perceived organization support and job satisfaction and the result was consistent with previous literature. In other studies, (Imran et al., 2014; Miao \& Kim, 2010) POS positively influence on Job satisfaction. 
Based on these ideas, hypothesis 2 is as follows:

H.2 Employee's POS positively influence on Job Satisfaction

Employees feel that they need to reciprocate, and generally do so in positive way that are beneficial to the organization, when organization acts in a positive way toward them (Eder \& Eisenberger, 2008). It is believed that high level of POS induces strong feelings of identification and trust with the organization, thus establishing exchange relationship (Settoon, Bennett, \& Liden, 1996). According to Tumwesigye (2010) if employees think that their organization appreciates their efforts for organization and cares about their comfort and welfare, those employees will likely to be stayed in the organization for longer period of time and will be more committed. Same findings by Allen, et al. (2003), also explained that low scores on turnover intention and actual turnover intention was associated with high POS scores. Conversely, the employee is less likely to remain with the organization if the organization has not acted positively towards an employee. Thus hypothesis 3 is as follows:

H.3 POS is negatively related with Turnover intention

\subsection{The Relationship among Trust, Job Satisfaction and Turnover Intention}

From most recent 15 years or so, trust has progressed toward becoming and pulled in enormous interest for social sciences. The etymological underlying foundations of trust in more established dialect meaning dependability and faithfulness. The occurrence of trust is start with the human association (Möllering, Bachmann, \& Hee Lee, 2004). The development of this phenomenon can be defined through social exchange theory that assumes trust ascends by repeated exchange of beneficial exchange among individuals. Because of the informal assurance of reciprocation in social exchange, trust takes times to develop as individuals prove they can be trusted. According to Rotter (1967) trust is "a generalized expectancy held by an individual that the word of another, can be relied on" (p. 651). One party end up powerless in light of the expectation that the other party will do critical activity to the trustor (Mayer, Davis, \& Schoorman, 1995). Studies have shown that, there is positive relationship between trust and OCB, fairness of supervision and job satisfaction and other relationships (Wang \& Lu, 2012).

In a study Driscoll (1978) concluded that trust is a strong predictor of Job performance. Trust has demonstrated a substantial relationship with various attitudinal variables like, organizational performance, turnover intention and job satisfaction (Dirks \& Ferrin, 2002). According to Wech (2002) the trust context is positively associated with job satisfaction. Rich (1997)also found trust as a moderator on role modeling on job satisfaction and performance. Trust between sale manager and sales person also effect job satisfaction (Lagace, 1991) and job satisfaction had positive relationship with trust at peer level too (Cook \& Wall, 1980). Based on above discussions, hypothesis 4 is as follows

H.4 Trust positively and significantly related with job satisfaction.

Trust is also strongly related with turnover intention (DeConinck, 2011; Harhara et al., 2015; Jay Prakash Mulki et al., 2006; Jay P Mulki, Jaramillo, \& Locander, 2008). Balkan, Serin, 
and Soran (2014) found that there is correlation between trust and turnover intention. Dirks and Ferrin (2002), in meta-analysis found that several outcomes, including turnover, was originated by trust. According to (Ferres, Connell, \& Travaglione, 2004) coworkers trust was the significant predictor of turnover intention. There is lower intention to leave when employees trust on supervisor (Jay P Mulki et al., 2008). Trust showed ample relation with intention to leave (Dirks \& Ferrin, 2002). It was found that trust was a significant originator of intention to leave, in a study done by (Jay Prakash Mulki et al., 2006) on salespersons. Based on this discussion, hypothesis 5 is as follows

H.5 Trust is negatively related to turnover intention.

\subsection{The Relationship between Job Satisfaction and Turnover Intention}

According to (Bhuian \& Mengue, 2002) job satisfaction is the volume to which workers feel about the domain of his/her job positively or negatively. Employees evaluate themselves and their job in the organization and this evaluation enables them to know if he/she is satisfied or not. (Misener, Haddock, Gleaton, \& Ajamieh, 1996) found that job satisfaction includes many facets of satisfaction related to supervision, working condition, benefits. A number of researches have done on job satisfaction and labor turnover (Coomber \& Barriball, 2007; Saeed et al., 2014; Spector, 1997).

Turnover intention is directly influenced by job satisfaction (Blau, 1987). Zeffane and Bani Melhem (2017) found that more satisfied employees are less inclined to leave. Employees' turnover intention and job satisfaction is associated (Spector, 1997). According to Vroom (1964) there is direct association between job satisfaction and turnover intention. Employees always compare their jobs with other alternative (because they think to leave) so they can have them by leaving current jobs. According to (Saeed et al., 2014) there is negative and significant relationship with job satisfaction and turnover intention. Hellman found that employees find other employment opportunity if they are dissatisfied from their job. Same has been found in many studies which indicate that turnover intention is likely to be less if employees are satisfied (Coomber \& Barriball, 2007; Hayes et al., 2006). Thus the hypothesis 6 is as follow

H.6 Job satisfaction negatively and significantly affect turnover intention.

\subsection{The Mediating Effect of Job Satisfaction}

In above literature, it is stated that variable namely POS, trust, significantly affect job satisfaction and turnover intention. It is also stated that job satisfaction significantly affects turnover intention. So we suppose that job satisfaction plays mediating role in hypothesis 7 and 8.

H.7 Through the mediating effect of job satisfaction POS reduces the employees' intention to leave.

H.8 Through the mediating effect of job satisfaction trust reduces the employees' intention to leave. 


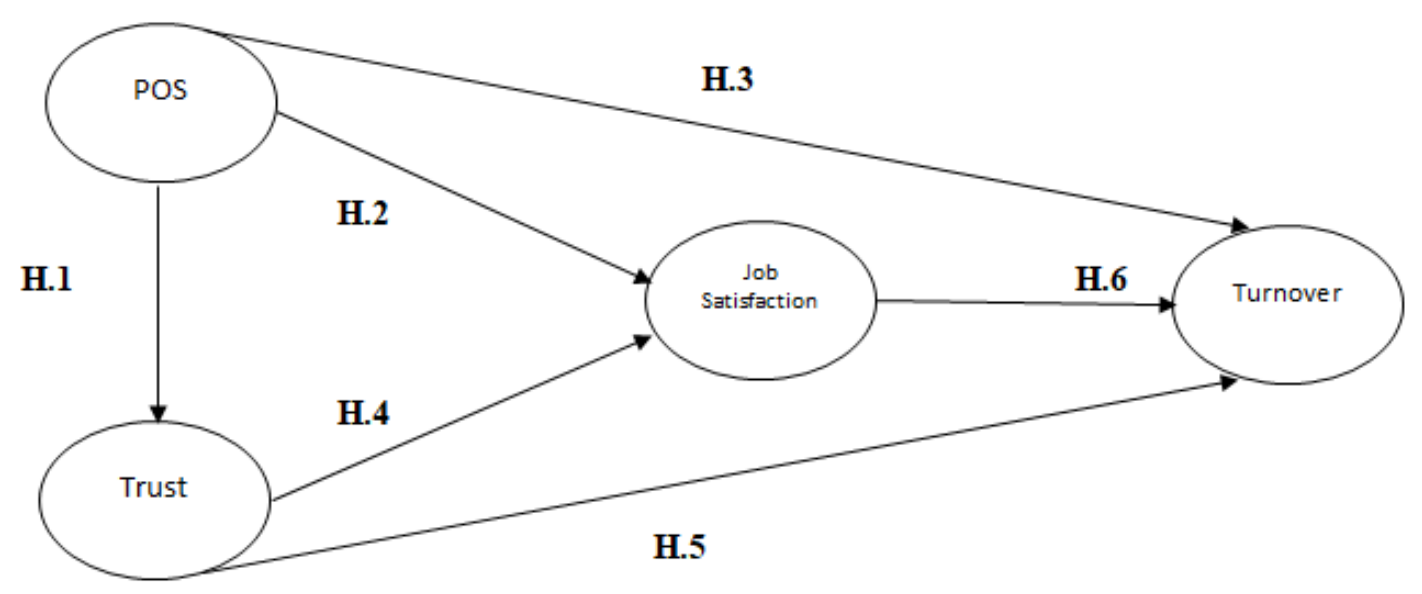

Figure 1. Research model

\section{Methodology}

\subsection{Participants and Procedure}

This research studied the relationship between employees' POS, trust, job satisfaction and turnover intention. The study established the basic research model, fig. 1 shows that POS and trust is independent variable; turnover intention is dependent variable; job satisfaction is the mediator variable.

A total of 300 questionnaires were distributed and 290 were returned. 9 questionnaires were partly completed so they were eliminated. A total of 281 samples were collected within March 10, 2018 to April 4, 2018. Table 1 shows that most respondents were male: 212 participants $(75.4 \%)$. Some 97 participants $(34.5 \%)$ were aged 26 to 30, and another 85 participants were aged 31 to 35 (30.2\%). Educational levels mostly were bachelor 148 $(52.7 \%)$ and 147 (52.3\%) had less than 6 years' experience. A survey was conducted to gather data from banks. A permission was taken from all the banks and respondents responded voluntarily. They were given to realize that their answers would stay classified. Ethical measures were taken to protect the rights of the participants throughout the study.

\subsection{Measures}

We targeted individuals employed in banking sector. The study collected data through questionnaire with five sections: POS, trust, job satisfaction, turnover intention and basic respondent demographics. The survey used the five point Likert scale ranging from one (strongly agree) to five (strongly disagree) for each scale. The 8 item-scale in the POS section (e.g., "The organization values my contribution to its well-being.") was adopted from (Rhoades \& Eisenberger, 2002). The 7-item scale in the trust section (e.g., "Most people can be counted on to what they say they will do.") was adopted, developed by (Mayer \& Davis, 1999) derived from Rotter's (1967) original trust scale, it is also used by (Zeffane \& Bani Melhem, 2017). The 6 item-scale in the job satisfaction section (e.g., "I would not consider working for another job.”) taken from the study of (Zeffane \& Bani Melhem, 2017) originally developed by (Brayfield \& Rothe, 1951). The 5 item-scale in the section (e.g., "I am seriously 
considering leaving in the near future.") of turnover intention was adopted, developed and validated by (Simmons, Cochran, \& Blount, 1997). Convenience sampling was used. This study used SPSS for descriptive analysis, reliability analysis, and regression.

Table 1. Characteristics of respondents

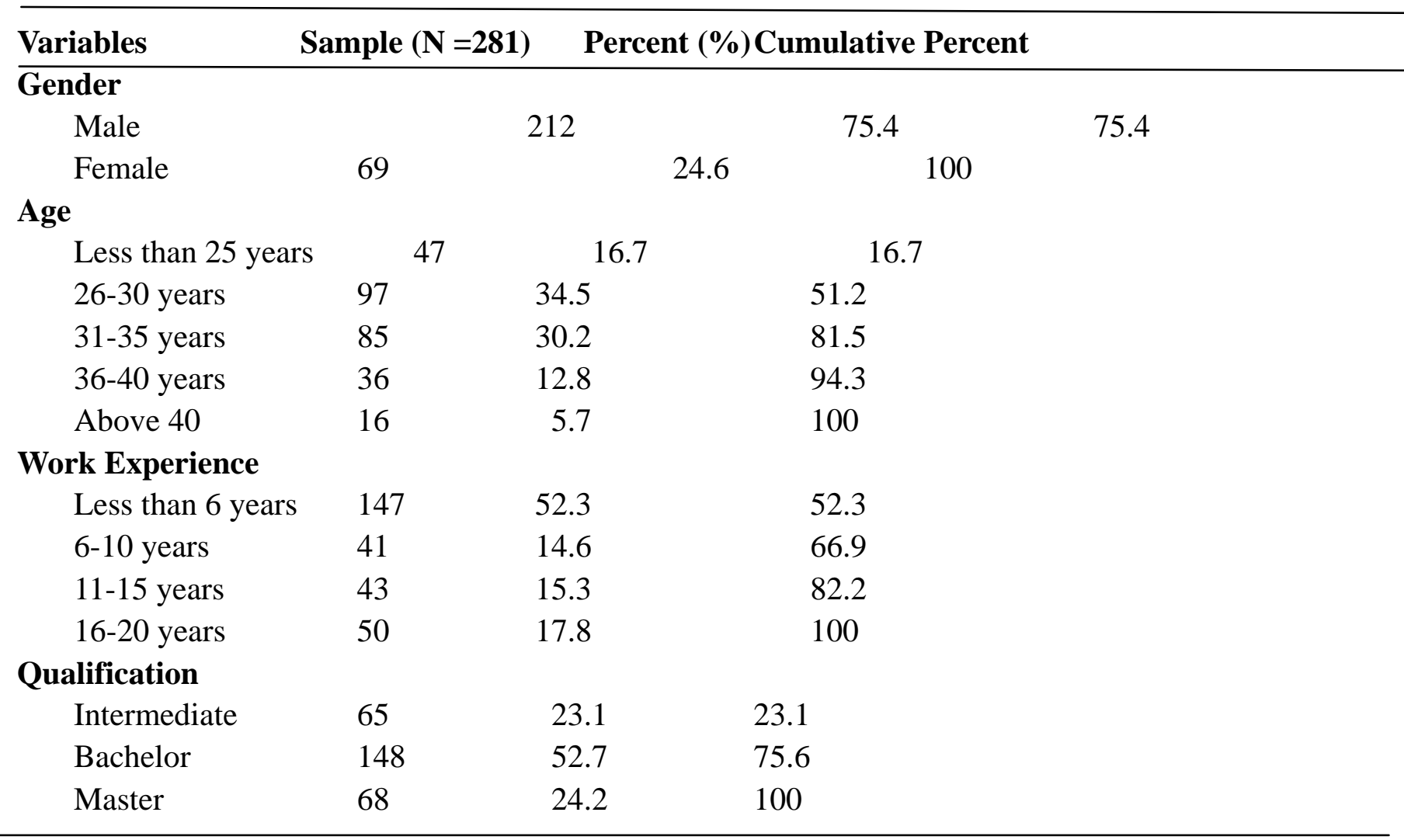

\subsection{Regression Analysis}

For examining the proposed relationship, a series of multiple regression analysis were performed. This study utilized the Baron and Kenny (1986) testing approach to deal with check whether job satisfaction was an intervening variable. The methodology for regression examinations are as per the following: (1) check the relation between (regression) dependent variable on the independent variable (Path C); (2) check the relation between (regression) intervening variable on the independent variable (Path $\mathrm{A}$ ); and (3) regressing the dependent variables on the independent variable (Path C') and mediator (Path B) (Baron \& Kenny, 1986)

If the independent variable (IV) is significant with the mediator, the intervening variable is significant in the (DV) dependent variable, and the independent variable (IV) is not significant on the dependent variable, there is likely a mediator between the independent variable and dependent variable (Baron and Kenny, 1986). Therefore, the study verified each hypothesis via a three-step approach: first 2 steps must be significant (1) the path regression between POS and trust; (2) regressing job satisfaction (the mediator) on POS and trust; (3) the path regression of POS, and trust on turnover intention; (4) regressing turnover intention (the dependent variable) on POS. trust and customer satisfaction. If POS and trust shows significance on job satisfaction, job satisfaction shows significance on turnover intention, 
then POS and trust shows no significance on Turnover intention, then job satisfaction is likely a mediator. If POS and trust still shows significance on job satisfaction, but the coefficients are condensed, it indicates that there is a partial mediator. In other words, POS and trust influence turnover intention directly and indirectly through job satisfaction.

\section{Research Findings}

\subsection{Descriptive Analysis}

The values, for all the variables, of mean and standard deviation are shown in table 2 . The turnover intention was negatively correlated with trust and job satisfaction. Positive correlation was there between job satisfaction and trust. For checking internal consistency of the result measurement reliability test was performed. According to (Sekaran, 1992)for checking multiple scales reliability alpha is the most mainstream measure. Values were all over the proposed cut-off of .70 (POS $=.79$; trust $=.81$; job satisfaction $=.89$; turnover intention $=.85$ ) thus indicating internal consistency (Nunnally, 1978).

Table 2. Descriptive analyses

\begin{tabular}{llllllllllll}
\hline $\mathrm{N}=281$ & \multicolumn{3}{c}{ Mean (S.D.) } & & \multicolumn{3}{l}{ Cronbach's } & \multicolumn{1}{l}{ Correlation } \\
\hline 1. & POS & 2.1085 & $(.59)$ & .79 & & 1 & & & & & \\
2. & Trust & 1.6028 & $(.49)$ & & .81 & & .44 & 1 & & & \\
3. Job satisfaction & 2.3294 & $(.64)$ & & .89 & & .69 & .55 & 1 & \\
4. & Turnover intention & 2.3665 & $(.67)$ & & .85 & & $-.80-.61-.701$ & 1 \\
\hline
\end{tabular}

\subsection{Hypothesis Testing}

Table. 3 shows the regression equations which were conducted in this study. Hypothesis 1 was tested with the help of equation 1 which proposes that b1 should be significant and positive. And other hypotheses were tested by other three equations. Hypotheses 2 and 3 propose that b1 and b2 should be significant and positive in Eq. (2). In Eq. (3), Hypotheses 4 and 5 suggest that b1 and b2 should be statistically significant and negative. Finally, in the last equation, Hypothesis 6 proposes that $\mathrm{b} 3$ must be significant. It was also expected that $\mathrm{b} 1$ and b2 would be weaker in the last equation while b3 would be significant.

Results are presented in table.4. Equation 1 shows that POS positively and significantly affected Trust (POS $\rightarrow$ T: $0.44, \mathrm{p}<0.001, \mathrm{R}=.24$ ); thus validating hypothesis 1 . Equation 2 confirms that POS and trust significantly and positively related to job satisfaction (POS $\rightarrow$ JS: $0.501, \mathrm{p}<0.05 ; \mathrm{T} \rightarrow \mathrm{JS}: .680, \mathrm{p}<0.001)$ therefore hypothesis 2 and 4 was supported. Equation 3 also confirmed that POS and trust significantly and negatively influenced turnover intention (POS $\rightarrow$ TI: $-.485, \mathrm{p}<0.05 ; \mathrm{T} \rightarrow \mathrm{TI}:-.791, \mathrm{p}<0.001$ ), hence supporting $3^{\text {rd }}$ and $5^{\text {th }}$ hypothesis. In equation 4 , it is shown that job satisfaction had significant and negative effect on turnover intention satisfaction (JS $\rightarrow$ TI: -.401), validating hypothesis 6 . The equation 3 indicated that POS and Trust had relatively high value and was significant. But in Eq.4 effect of POS and trust on turnover intention was relatively low but still significant. So it means job 
satisfaction was not a full mediator in this study perhaps the coefficients were condensed and job satisfaction played the role of partial mediator. There was not full mediation but the effect of trust and POS was condensed. Meaning of this, trust influenced directly and indirectly through partial mediation of job satisfaction and POS influence negatively through mediation. Fig. 2 shows the research findings, and Table 4 summarizes the hypothesis results.

Table 3. Multiple regression Equations

$$
\begin{aligned}
& \mathrm{T}=\beta \mathrm{o}+\beta 1 \mathrm{POS}+\mathrm{e} \\
& \mathrm{JS}=\beta \mathrm{o}+\beta 1 \mathrm{POS}+\beta 2 \mathrm{~T}+\mathrm{e} \\
& \mathrm{TI}=\beta \mathrm{o}+\beta 1 \mathrm{POS}+\beta 2 \mathrm{~T}+\mathrm{e} \\
& \mathrm{TI}=\beta \mathrm{o}+\beta 1 \mathrm{POS}+\beta 2 \mathrm{~T}+\beta 3 \mathrm{JS}+\mathrm{e}
\end{aligned}
$$

NOTE: POS: Perceived organizational support; TI: turnover intention; JS: job satisfaction; T: trust; $\beta$ : regression coefficient; e: error term

\section{Discussion}

\subsection{The Relationships among POS, Trust, Job Satisfaction a Turnover Intention}

The results displayed that POS positively affected trust and job satisfaction and negatively related with turnover intention. Once the organizations/ institutes give support to their employees and value their commitment, it would make the environment trustworthy, employees trust each other and ultimately go for job satisfaction. The findings of study echoed previous research (Ristig, 2009), that POS positively and significantly affect trust. POS was also positively associated with job satisfaction and it was according to the previous studies. Yih-Wann, Wu., \& Htaik, Sein. (2011) found that POS was positively associated with job satisfaction. POS was negatively related with turnover intention and it have been proved in previous studies too. Allen et al. (2003), found that POS was related with turnover intention and actual turnover. When employees perceive support from their organization and

\begin{tabular}{|c|c|c|c|c|c|}
\hline \multicolumn{2}{|c|}{ Independent variable } & Dependent variable & \multicolumn{2}{|c|}{ Regression coefficients } & $\mathrm{t}$ value \\
\hline & POS & 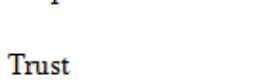 & $\begin{array}{c}\text { Unstandardized } \\
.61\end{array}$ & $\begin{array}{l}\text { Standardized } \\
.44\end{array}$ & $9.59 * *$ \\
\hline Eq. (1) & \multicolumn{5}{|c|}{ R2 (adjusted R2) $.25(.24)$} \\
\hline \multirow[t]{3}{*}{ Eq. (2) } & POS & Job satisfaction & .498 & .501 & \multirow[t]{3}{*}{$8.063 * *$} \\
\hline & Trust & Job satisfaction & .716 & .680 & \\
\hline & $\mathrm{R} 2$ (adjusted $\mathrm{F}$ & 22) $.58(.58)$ & & & \\
\hline \multirow[t]{3}{*}{ Eq. (3) } & POS & Tumover intention & -.351 & -.485 & $-7.87 * *$ \\
\hline & Trust & Tumover intention & -.601 & -.791 & $-11.02 * *$ \\
\hline & \multicolumn{5}{|c|}{ R2 (adjusted R2) .59(.59) } \\
\hline \multirow[t]{3}{*}{ Eq. (4) } & POS & Tumover intention & -.401 & -.264 & $-2.70 * *$ \\
\hline & Trust & Tumover intention & -.701 & -.691 & $-2.55^{* *}$ \\
\hline & \multicolumn{2}{|c|}{$\begin{array}{l}\text { Job satisfaction Tumover intention } \\
\text { R2 (adjusted R2).72 (.71) }\end{array}$} & -.612 & -.401 & $-5.57 * *$ \\
\hline
\end{tabular}
if organization cares about well-being of its employees, employees are likely to stay in the organizations.

Table 4. Regression estimates of equations 


\section{Macrothink}

International Journal of Human Resource Studies

ISSN 2162-3058

2018, Vol. 8, No. 4

\subsection{The relation of Trust with Job Satisfaction and Turnover Intention}

The findings of the study showed that trust positively affected job satisfaction and negatively affected turnover intention. One the organizations/ institutes make the environment trustworthy, employees trust each other and ultimately go for job satisfaction. The findings of study showed result as previous research (Wech, 2002), that trust positively affect job satisfaction. The results of this study suggest that trust negatively and significantly affect turnover intention. If the employee has trust workers and in supervisor, he is less likely to leave. This result is consistent with previous findings that trust is a significant predictor of turnover intention (Ferres et al., 2004; Jay Prakash Mulki et al., 2006; Zeffane \& Bani Melhem, 2017).

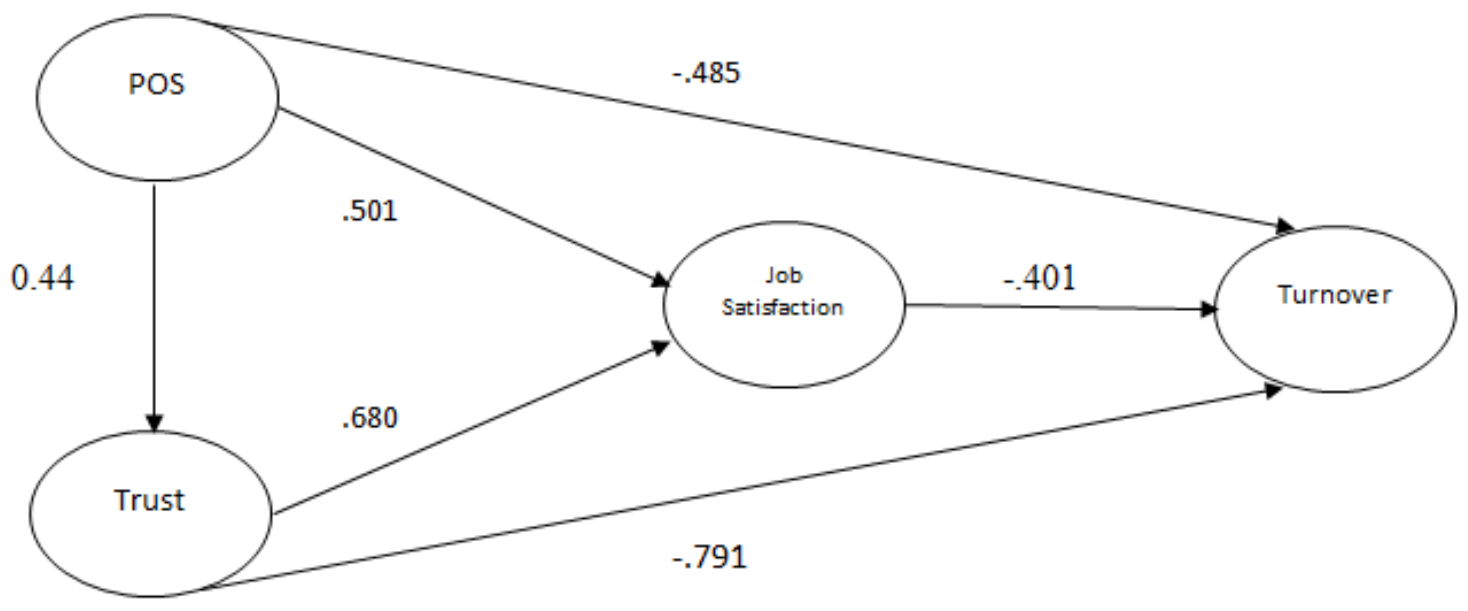

Figure 2. Resultant model

\subsection{The Mediating Effects of Job Satisfaction}

The study proved the relation of POS and trust on job satisfaction and also examined the relation between job satisfaction and turnover intention. Same with previous studies (Coomber \& Barriball, 2007; Saeed et al., 2014), job satisfaction negatively influenced turnover intention. Job satisfaction effect significantly and plays a role of partial mediator between trust and turnover intention meaning that POS and trust influence turnover intention directly as well as directly through job satisfaction. Karatepe and Karadas (2012) said POS might influence turnover intention indirectly but in our study POS influence directly as well as indirectly.

\section{Conclusion}

\subsection{Conclusion}

The study tested all variables POS, trust, job satisfaction and turnover intention as the research framework. Cause and effect relationship among variables were examined. The study proved that POS and trust positively influenced job satisfaction and negatively influenced turnover intention, as did job satisfaction. Job satisfaction showed a partial mediation effect between POS, trust and turnover intention. Although POS had more effect on turnover intention than trust. The study proved that job satisfaction gets increased with 
high level of trust among coworkers and caring employees, giving support to them. It also helps to reduce turnover intention.

\subsection{Academic Contribution and Practical Suggestion}

POS, trust, job satisfaction, and turnover intention all are related with each other, our study proved it, so it supported past research. The uniqueness of this study that the relationship between POS, trust, job satisfaction and turnover intention was investigated all together; using POS and trust as independent with turnover intention as dependent variable to prove job satisfaction is the partial mediator. The findings of the examination are likewise one of a kind in the social setting of Pakistan as no such investigation has been conveyed to date. In addition, this exploration work can likewise be considered as a valuable commitment towards giving a frame of reference and exact proof for managers in banking sector to manage the issue of employee's turnover. The study found that POS and trust effect job satisfaction and turnover intention significantly. POS showed significantly effect on trust, job satisfaction, and turnover intention. So banking supervisors must consider POS prior to any other variable.

\subsection{Research Limitations and Future Research Suggestions}

Research subjects was banking sectors' employees, so this study only applies to banking sector and cannot be extended. Mostly respondents were male so question might raise on gender discrimination. The time was limited so sampling technique can be changed and sample size can be increased in future research. Mixed or multiple method can be used in future research for better results. In this study, POS and trust was used as independent variables, future researches may use other independent variables. Other sectors like educational and health sector can be taken into account in future.

\section{References}

Allen, D. G., Shore, L. M., \& Griffeth, R. W. (2003). The role of perceived organizational support and supportive human resource practices in the turnover process. Journal of management, 29(1), 99-118. https://doi.org/10.1177/014920630302900107

Aselage, J., \& Eisenberger, R. (2003). Perceived organizational support and psychological contracts: A theoretical integration. Journal of Organizational Behavior: The International Journal of Industrial, Occupational and Organizational Psychology and Behavior, 24(5), 491-509. https://doi.org/10.1002/job.211

Balkan, M. O., Serin, A. E., \& Soran, S. (2014). The relationship between trust, turnover intentions and emotions: An application. European Scientific Journal, ESJ, 10(2).

Baron, R. M., \& Kenny, D. A. (1986). The moderator-mediator variable distinction in social psychological research: Conceptual, strategic, and statistical considerations. Journal of personality and social psychology, 51(6), 1173. https://doi.org/10.1037/0022-3514.51.6.1173

Bhuian, S. N., \& Mengue, B. (2002). An extension and evaluation of job characteristics, organizational commitment and job satisfaction in an expatriate, guest worker, sales setting. Journal of Personal Selling \& Sales Management, 22(1), 1-11. 
Blau, G. J. (1987). Locus of control as a potential moderator of the turnover process. Journal $\begin{array}{llll}\text { of Occupational } & \text { Psychology, } & \text { 21-29. }\end{array}$ https://doi.org/10.1111/j.2044-8325.1987.tb00238.x

Blau, P. (1964). 1964 Exchange and power in social life. New York: Wiley.

Brayfield, A. H., \& Rothe, H. F. (1951). An index of job satisfaction. Journal of applied psychology, 35(5), 307. https://doi.org/10.1037/h0055617

Bright, L. (2008). Does public service motivation really make a difference on the job satisfaction and turnover intentions of public employees? The American Review of Public Administration, 38(2), 149-166. https://doi.org/10.1177/0275074008317248

Cook, J., \& Wall, T. (1980). New work attitude measures of trust, organizational commitment and personal need non-fulfilment. Journal of Occupational Psychology, 53(1), 39-52. https://doi.org/10.1111/j.2044-8325.1980.tb00005.x

Coomber, B., \& Barriball, K. L. (2007). Impact of job satisfaction components on intent to leave and turnover for hospital-based nurses: a review of the research literature. International journal of nursing studies, 44(2), 297-314. https://doi.org/10.1016/j.ijnurstu.2006.02.004

DeConinck, J. B. (2011). The effects of ethical climate on organizational identification, supervisory trust, and turnover among salespeople. Journal of Business Research, 64(6), 617-624. https://doi.org/10.1016/j.jbusres.2010.06.014

Dirks, K. T., \& Ferrin, D. L. (2002). Trust in leadership: meta-analytic findings and implications for research and practice. Journal of Applied psychology, 87(4), 611. https://doi.org/10.1037/0021-9010.87.4.611

Driscoll, J. W. (1978). Trust and participation in organizational decision making as predictors of satisfaction. Academy of Management journal, 21(1), 44-56.

Eder, P., \& Eisenberger, R. (2008). Perceived Organizational Support: Reducing the Negative Influence of Coworker Withdrawal Behavior. Journal of management, 34(1), 55-68. https://doi.org/10.1177/0149206307309259

Eisenberger, R., Huntington, R., Hutchison, S., \& Sowa, D. (1986). Perceived organizational $\begin{array}{lllll}\text { support. Journal of } & \text { Applied }\end{array}$ https://doi.org/10.1037/0021-9010.71.3.500

Ferres, N., Connell, J., \& Travaglione, A. (2004). Co-worker trust as a social catalyst for constructive employee attitudes. Journal of Managerial Psychology, 19(6), 608-622. https://doi.org/10.1108/02683940410551516

Harhara, A. S., Singh, S. K., \& Hussain, M. (2015). Correlates of employee turnover intentions in oil and gas industry in the UAE. International journal of organizational analysis, 23(3), 493-504. https://doi.org/10.1108/IJOA-11-2014-0821 
Hayes, L. J., O’Brien-Pallas, L., Duffield, C., Shamian, J., Buchan, J., Hughes, F., . . Stone, P. W. (2006). Nurse turnover: a literature review. International journal of nursing studies, 43(2), 237-263. https://doi.org/10.1016/j.ijnurstu.2005.02.007

Hellman, C. M. (1997). Job satisfaction and intent to leave. The Journal of Social Psychology, 137(6), 677-689. https://doi.org/10.1080/00224549709595491

Imran, M., Ali, G., \& Islam, T. (2014). The relationship between perceived organizational support and turnover intention: mediating role of affective commitment and job satisfaction. Research Journal of Applied Sciences, Engineering and Technology, 8(24), 2422-2425. https://doi.org/10.19026/rjaset.8.1249

Islam, T., Khan, M. M., \& Bukhari, F. H. (2016). The role of organizational learning culture and psychological empowerment in reducing turnover intention and enhancing citizenship behavior. The Learning Organization, 23(2/3), 156-169. https://doi.org/10.1108/TLO-10-2015-0057

Karatepe, O. M., \& Karadas, G. (2012). The effect of management commitment to service quality on job embeddedness and performance outcomes. Journal of Business Economics and Management, 13(4), 614-636. https://doi.org/10.3846/16111699.2011.620159

Lagace, R. R. (1991). An exploratory study of reciprocal trust between sales managers and salespersons. Journal of Personal Selling \& Sales Management, 11(2), 49-58.

Mayer, R. C., \& Davis, J. H. (1999). The effect of the performance appraisal system on trust for management: A field quasi-experiment. Journal of applied psychology, 84(1), 123. https://doi.org/10.1037/0021-9010.84.1.123

Mayer, R. C., Davis, J. H., \& Schoorman, F. D. (1995). An integrative model of organizational trust. Academy of management review, 20(3), 709-734. https://doi.org/10.5465/amr.1995.9508080335

Miao, R., \& Kim, H.-G. (2010). Perceived organizational support, job satisfaction and employee performance: An Chinese empirical study. Journal of Service Science and Management, 3(02), 257. https://doi.org/10.4236/jssm.2010.32032

Misener, T. R., Haddock, K. S., Gleaton, J. U., \& Ajamieh, A. R. A. (1996). Toward an international measure of job satisfaction. Nursing research, 45(2), 87-91. https://doi.org/10.1097/00006199-199603000-00006

Möllering, G., Bachmann, R., \& Hee Lee, S. (2004). Introduction: Understanding organizational trust-foundations, constellations, and issues of operationalisation. Journal of Managerial Psychology, 19(6), 556-570. https://doi.org/10.1108/02683940410551480

Mulki, J. P., Jaramillo, F., \& Locander, W. B. (2006). Effects of ethical climate and supervisory trust on salesperson's job attitudes and intentions to quit. Journal of Personal Selling \& Sales Management, 26(1), 19-26. https://doi.org/10.2753/PSS0885-3134260102 
Mulki, J. P., Jaramillo, J. F., \& Locander, W. B. (2008). Effect of ethical climate on turnover intention: Linking attitudinal-and stress theory. Journal of Business Ethics, 78(4), 559-574. https://doi.org/10.1007/s10551-007-9368-6

Narang, L., \& Singh, L. (2012). Role of perceived organizational support in the relationship between HR practices and organizational trust. Global Business Review, 13(2), 239-249. https://doi.org/10.1177/097215091201300204

Nunnally, J. (1978). Psychometric methods. In: New York: McGraw-Hill.

Rhoades, L., \& Eisenberger, R. (2002). Perceived organizational support: a review of the $\begin{array}{lllll}\text { literature. Journal of applied } & \text { psychology, } & 87(4), & 698 .\end{array}$ https://doi.org/10.1037/0021-9010.87.4.698

Rich, G. A. (1997). The sales manager as a role model: Effects on trust, job satisfaction, and performance of salespeople. Journal of the Academy of Marketing Science, 25(4), 319-328. https://doi.org/10.1177/0092070397254004

Ristig, K. (2009). The impact of perceived organizational support and trustworthiness on trust. Management Research News, 32(7), 659-669. https://doi.org/10.1108/01409170910965251

Robbins, S. P., Judge, T. A., \& Sanghi, S. (2005). Organizational behaviour 11 th Edition. In: Prentice Hall India.

Rotter, J. B. (1967). A new scale for the measurement of interpersonal trust 1. Journal of personality, 35(4), 651-665. https://doi.org/10.1111/j.1467-6494.1967.tb01454.x

Saeed, I., Waseem, M., Sikander, S., \& Rizwan, M. (2014). The relationship of turnover intention with job satisfaction, job performance, leader member exchange, emotional intelligence and organizational commitment. International Journal of Learning and Development, 4(2), 242-256. https://doi.org/10.5296/ijld.v4i2.6100

Sekaran, U. (1992). Research Methods For Business, Canada. In: John Wiley ve Sons, Inc.

Settoon, R. P., Bennett, N., \& Liden, R. C. (1996). Social exchange in organizations: Perceived organizational support, leader-member exchange, and employee reciprocity. Journal of applied psychology, 81(3), 219. https://doi.org/10.1037/0021-9010.81.3.219

Shukla, A., \& Rai, H. (2015). Linking perceived organizational support to organizational trust and commitment: moderating role of psychological capital. Global Business Review, 16(6), 981-996. https://doi.org/10.1177/0972150915597599

Simmons, C., Cochran, J. K., \& Blount, W. R. (1997). The effects of job-related stress and job satisfaction on probation officers' inclinations to quit. American Journal of Criminal Justice, 21(2), 213-229. https://doi.org/10.1007/BF02887450

Spector, P. E. (1997). Job satisfaction: Application, assessment, causes, and consequences (Vol. 3): Sage publications. 


\section{Macrothink}

International Journal of Human Resource Studies

ISSN 2162-3058 2018, Vol. 8, No. 4

Stinglhamber, F., Cremer, D. D., \& Mercken, L. (2006). Perceived support as a mediator of the relationship between justice and trust: A multiple foci approach. Group \& Organization Management, 31(4), 442-468. https://doi.org/10.1177/1059601106286782

Tumwesigye, G. (2010). The relationship between perceived organisational support and turnover intentions in a developing country: The mediating role of organisational commitment. African Journal of Business Management, 4(6), 942-952.

Vroom, V. H. (1964). Work and motivation. 1964. NY: John Wiley \&sons, 45.

Wang, H., \& Lu, Y. (2012). Trust governance based on active interpersonal strategy. Nankai business review international, 3(2), 128-144. https://doi.org/10.1108/20408741211244361

Wayne, S. J., Shore, L. M., \& Liden, R. C. (1997). Perceived organizational support and leader-member exchange: A social exchange perspective. Academy of Management journal, $40(1), 82-111$.

Wech, B. A. (2002). Trust context: Effect on organizational citizenship behavior, supervisory fairness, and job satisfaction beyond the influence of leader-member exchange. Business \& Society, 41(3), 353-360. https://doi.org/10.1177/0007650302041003006

Zeffane, R., \& Bani Melhem, S. J. (2017). Trust, job satisfaction, perceived organizational performance and turnover intention: A public-private sector comparison in the United Arab Emirates. Employee Relations, 39(7), 1148-1167. https://doi.org/10.1108/ER-06-2017-0135

\section{Copyright Disclaimer}

Copyright for this article is retained by the author(s), with first publication rights granted to the journal.

This is an open-access article distributed under the terms and conditions of the Creative Commons Attribution license (http://creativecommons.org/licenses/by/4.0/). 